\title{
Early Entrance Coproduction Plant
}

\section{Phase II - Quarterly Report No. 16}

Reporting period: July 1, 2003 - September 30, 2003

Contributors: Mushtaq Ahmed (Praxair)

John H. Anderson (TES)

Earl R. Berry (TES)

Troy Raybold (Praxair)

Lalit S. Shah (ChevronTexaco)

Kenneth A. Yackly (GE)

Date Issued: $\quad$ November 25, 2003 (Preliminary)

December 16, 2003 (Final)

\section{DOE Cooperative Agreement No. DE-FC26-99FT40658}

Texaco Energy Systems LLC

3901 Briarpark Drive

Houston, Texas 77042 


\section{Disclaimer:}

This report was prepared as an account of work sponsored by an agency of the United States Government. Neither the United States Government nor any agency thereof, nor any of their employees, makes any warranty, express or implied, or assumes any legal liability or responsibility for the accuracy, completeness, or usefulness of any information, apparatus, product, or process disclosed, or represents that its use would not infringe privately owned rights. Reference herein to any specific commercial product, process, or service by trade name, trademark, manufacturer, or otherwise does not necessarily constitute or imply its endorsement, recommendation, or favoring by the United States Government or any agency thereof. The views and opinions of authors expressed herein do not necessarily state or reflect those of the United States Government or any agency thereof. 


\section{Abstract:}

The overall objective of this project is the three phase development of an Early Entrance Coproduction Plant (EECP) which uses petroleum coke to produce at least one product from at least two of the following three categories: (1) electric power (or heat), (2) fuels, and (3) chemicals. The objective is to have these products produced by technologies capable of using synthesis gas derived from coal and/or other carbonaceous feedstocks.

The objectives of Phase I were to determine the feasibility and define the concept for the EECP located at a specific site; develop a Research, Development, and Testing (RD\&T) Plan for implementation in Phase II; and prepare a Preliminary Project Financing Plan.

The objective of Phase II is to implement the work as outlined in the Phase I RD\&T Plan to enhance the development and commercial acceptance of coproduction technology that produces high-value products, particularly those that are critical to our domestic fuel and power requirements. The work performed under Phase II will resolve critical knowledge and technology gaps on the integration of gasification and downstream processing to coproduce some combination of power, fuels, and chemicals from coal and/or other carbonaceous feedstocks.

The objective of Phase III is to develop an engineering design package and a financing and testing plan for an EECP located at a specific site.

The project's intended result is to provide the necessary technical, economic, and environmental information needed by industry to move the EECP forward to detailed design, construction, and operation. 


\section{Table of Contents}

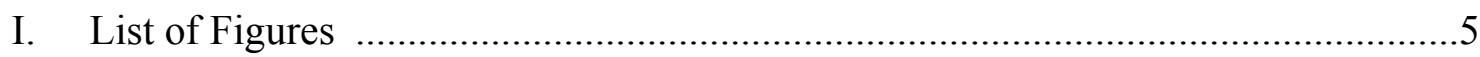

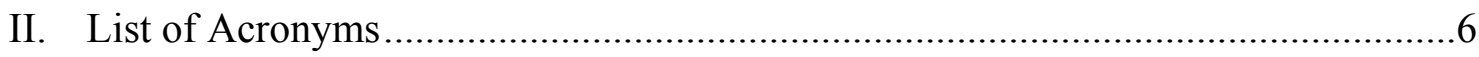

III. Executive Summary ………………………..............................................

IV. Results, Discussion and Preliminary Conclusions ..................................................

V. List of Major Activities Accomplished in Third $\left(3^{\text {rd }}\right)$ Calendar Quarter 2003........11

VI. List of Major Activities Planned for Fourth $\left(4^{\text {th }}\right)$ Calendar Quarter 2003...............12

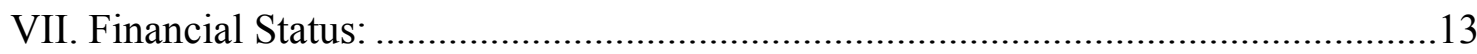

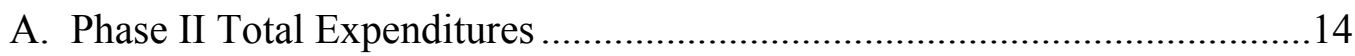

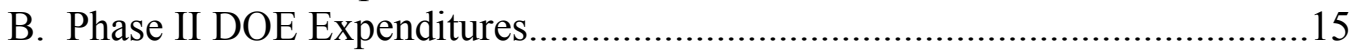

C. Phase II Total Percent Complete..................................................................16

VIII. Schedule - MS Project Schedule updated through September 30, 2003 ...............17

The Contractor can not confirm the authenticity of the information contained herein since this report is being submitted under the U.S. Department of Energy requirement that the electronic files must be submitted without being write-protected.

Note: Unless specified otherwise, all quarters/years are calendar quarters/years. 


\section{List of Figures}

The following figures were used in this report:

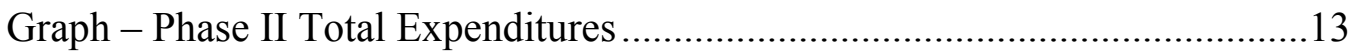

Graph - Phase II DOE Expenditures ............................................................14

Graph - Phase II Total Percent Complete..........................................................15

Phase II Project Schedule ..............................................................................16 


\section{List of Acronyms}

$\begin{array}{ll}\text { ASU } & \text { Air Separation Unit } \\ \text { Btu } & \text { British thermal unit } \\ \mathrm{CO}_{2} & \text { carbon dioxide } \\ \text { DOE } & \text { U.S. Department of Energy } \\ \text { EECP } & \text { Early Entrance Coproduction Plant } \\ \text { F-T } & \text { Fischer-Tropsch } \\ \text { GE } & \text { General Electric } \\ \text { KBR } & \text { Kellogg Brown \& Root } \\ \text { MDEA } & \text { methyldiethanolamine } \\ \text { RD\&T } & \text { Research, Development, and Testing } \\ \text { stpd } & \text { short tons per day } \\ \text { TES } & \text { Texaco Energy Systems LLC }\end{array}$




\section{Executive Summary}

This is the eleventh quarterly report which summarizes the progress of Phase II of the development of the Early Entrance Coproduction Plant (EECP) being performed under U.S. Department of Energy (DOE) Cooperative Agreement No. DE-FC26-99FT40658. The EECP will integrate advanced, high-efficiency, fuelflexible electrical power generation, from coal and/or other carbonaceous materials, with a facility capable of producing clean transportation fuels and/or chemicals. An industrial consortium consisting of Texaco Energy Systems LLC (TES), Kellogg Brown \& Root (KBR), General Electric (GE), Praxair, and Rentech Inc. is developing this project.

In the proposed EECP, approximately 1,235 short tons per day (stpd) petroleum coke is used to produce 55 megawatts of net electric power for export, approximately 617 barrels per day of Fischer-Tropsch (F-T) products (finished high-melt wax, finished low-melt wax, hydrotreated F-T diesel, and hydrotreated F-T naphtha), steam, and approximately 89 stpd of sulfur. Additionally, the air separation unit (ASU) will produce excess nitrogen and oxygen that will be exported.

The Phase I objective was to determine the feasibility and define the concept for the EECP located at a specific site, develop a Research, Development, and Testing (RD\&T) Plan, and prepare a Preliminary Project Financing Plan. Phase I was completed in December 2000 and the final Phase I Concept Report was issued in May 2001. In Phase I, a typical refinery site, Motiva Port Arthur, was identified as the potential EECP site. As a result of the merger between Texaco and Chevron, Texaco was required to sell its interest in the Motiva Enterprises LLC joint venture to Shell Oil Company and Saudi Refining Inc. For Phase III of the EECP project, at the present time, TES has recommended to DOE that the EECP Cooperative Agreement be concluded at the end of Phase II unless another project site can be identified.

The objective of Phase II is to conduct the research as outlined in the Phase I RD\&T Plan. Phase II was originally scheduled for two calendar years (2001 through 2002). The revised target for Phase II completion is the fourth $\left(4^{\text {th }}\right)$ calendar quarter of 2003.

During this reporting period, final topical reports for F-T Pilot Plant Confirmation (Task 2.1), F-T Catalyst/Wax Separation (Task 2.3), F-T Diesel Fuel/Engine Performance and Emissions (Task 2.6), Environmental (Task 2.10), and Update and Implement Essential RD\&T (Task 3.0) were approved by the DOE. The F-T Product Upgrading Topical Report (Task 2.5) and the Phase II Final Report were submitted to DOE for review. Additionally, TES has requested that DOE provide a no-cost time extension for Phase II of the EECP project from November 30, 2003 to March 31, 2004. The no-cost time extension would provide the 
opportunity to locate a new site and update the concept design basis prior to starting Phase III.

Phase III was envisioned to be a one-year effort scheduled to begin at the conclusion of Phase II. As discussed previously, TES has recommend to DOE that the Cooperative Agreement for the EECP Project be concluded at the end of Phase II unless another project site can be identified. An engineering design package, testing plan, and financing plan for the EECP was to be developed in Phase III. The overall project's intended result is to provide the necessary technical, economic, and environmental information needed by industry to move the EECP forward to detailed design, construction, and operation. 


\section{Results, Discussion, and Preliminary Conclusions}

\section{Task 1 Project Management}

Task completed. The updated Project Management Plan was approved by the DOE in the second $\left(2^{\text {nd }}\right)$ calendar quarter of 2001.

\section{Task 2.1 Fischer-Tropsch Pilot Plant Confirmation}

Task completed. The final Task 2.1 Topical Report was approved by the DOE in the third $\left(3^{\text {rd }}\right)$ calendar quarter of 2003.

Task 2.2 Fischer-Tropsch Mathematical Model and Reactor Scale-Up Confirmation Task completed. The final Task 2.2 Topical Report was approved by the DOE in the second $\left(2^{\text {nd }}\right)$ calendar quarter of 2003.

Task 2.3 Catalyst/Wax Separation

Task completed. The final Task 2.3 Topical Report was approved by the DOE in the third $\left(3^{\text {rd }}\right)$ calendar quarter of 2003.

Task 2.4 Low British Thermal Unit (Btu) Gas Combustion Test

Task completed. The final Task 2.4 Topical Report was approved by the DOE in the second $\left(2^{\text {nd }}\right)$ calendar quarter of 2003 .

\section{Task 2.5 F-T Product Upgrading}

The Task 2.5 Topical Report was submitted to DOE for review in the third $\left(3^{\text {rd }}\right)$ calendar quarter of 2003.

Task 2.6 F-T Diesel Fuel/Engine Performance and Emissions

Task completed. The final Task 2.6 Topical Report was approved by the DOE in the third $\left(3^{\text {rd }}\right)$ calendar quarter of 2003.

\section{Task 2.7 Petroleum Coke Analysis}

Task completed. The final Task 2.7 Topical Report was approved by the DOE in the second $\left(2^{\text {nd }}\right)$ calendar quarter of 2003 . 
Task 2.8 Carbon Dioxide $\left(\mathrm{CO}_{2}\right)$ Stripping from Methyldiethanolamine (MDEA) at Medium Pressure

Task completed. The final Task 2.8 Topical Report was approved by the DOE in the fourth $\left(4^{\text {th }}\right)$ calendar quarter of 2002 .

Task 2.9 Integration

Task completed. The final Task 2.9 Topical Report was approved by the DOE in the second $\left(2^{\text {nd }}\right)$ calendar quarter of 2003 .

Task 2.10 Environmental

Task completed. The final Task 2.10 Topical Report was approved by the DOE in the third $\left(3^{\text {rd }}\right)$ calendar quarter of 2003.

Task 3.0 Update and Implement Essential RD\&T

Task completed. The final Task 3.0 Topical Report was approved by the DOE in the third $\left(3^{\text {rd }}\right)$ calendar quarter of 2003 .

Task 4.0 Update to Phase I Design Basis Topical Report

Task completed. The final Task 4.0 Topical Report was approved by the DOE in the third $\left(3^{\text {rd }}\right)$ calendar quarter of 2003.

Phase II Final Report

The Phase II Final Report was submitted to DOE for review in the third $\left(3^{\text {rd }}\right)$ calendar quarter of 2003. 


\section{List of Major Activities Accomplished in the Third $\left(3^{\text {rd }}\right)$ Calendar Quarter of 2003}

The following list is provided as a quick reference for the work performed during this reporting period:

- Submitted Quarterly Report No. 15 for DOE review and approval.

- DOE approved Quarterly Report No. 15.

- Submitted final Task 2.1 Topical Report (F-T Pilot Plant Confirmation).

- DOE approved final Task 2.1 Topical Report (F-T Pilot Plant Confirmation).

- Submitted final Task 2.3 Topical Report (F-T Catalyst/Wax Separation).

- DOE approved final Task 2.3 Topical Report (F-T Catalyst/Wax Separation).

- Submitted Task 2.5 Topical Report (F-T Product Upgrading) for DOE review.

- Submitted final Task 2.6 Topical Report (F-T Diesel Fuel/Engine Performance and Emissions).

- DOE approved final Task 2.6 Topical Report (F-T Diesel Fuel/Engine Performance and Emissions).

- Submitted final Task 2.10 Topical Report (Environmental).

- DOE approved final Task 2.10 Topical Report (Environmental).

- Submitted final Task 3.0 Topical Report (Update and Implement Additional Research, Development, and Testing).

- DOE approved final Task 3.0 Topical Report (Update and Implement Additional Research, Development, and Testing).

- Submitted final Task 4.0 Topical Report (Update to Phase I Design Basis).

- DOE approved final Task 3.0 Topical Report (Update to Phase I Design Basis).

- Submitted the Phase II Final Report for DOE review.

- Requested a four (4)-month no-cost time extension for Phase II. 


\section{List of Major Activities Planned for the Fourth $\left(4^{\text {th }}\right)$ Calendar Quarter of 2003}

The following list is provided as a quick reference for the work planned for the upcoming quarter:

- Submit Quarterly Report No. 16 for DOE for review and approval.

- Submit the final Task 2.5 Topical Report (F-T Product Upgrading) to DOE for approval.

- Submit the final Phase II Final Report to DOE for approval.

- Identify potential new EECP site. 


\section{Financial Status}

The following three graphs depict the financial status and progress of Phase II activities. The graphs are shown on the following three pages:

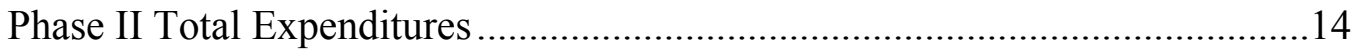

Phase II DOE Expenditures ..................................................................15

Phase II Total Percent Complete..............................................................16

Total planned expenditures for Phase II were expected to be $\$ 6,158,738$ (DOE share is $\$ 4,003,180)$. Based on the work completed, the final Phase II expenditures are expected to less than the planned amount. Final Phase II DOE expenditures are expected to be approximately $\$ 600,000$ below the budget amount. 


\section{Early Entrance Coproduction Plant}

Phase II - Total Expenditures

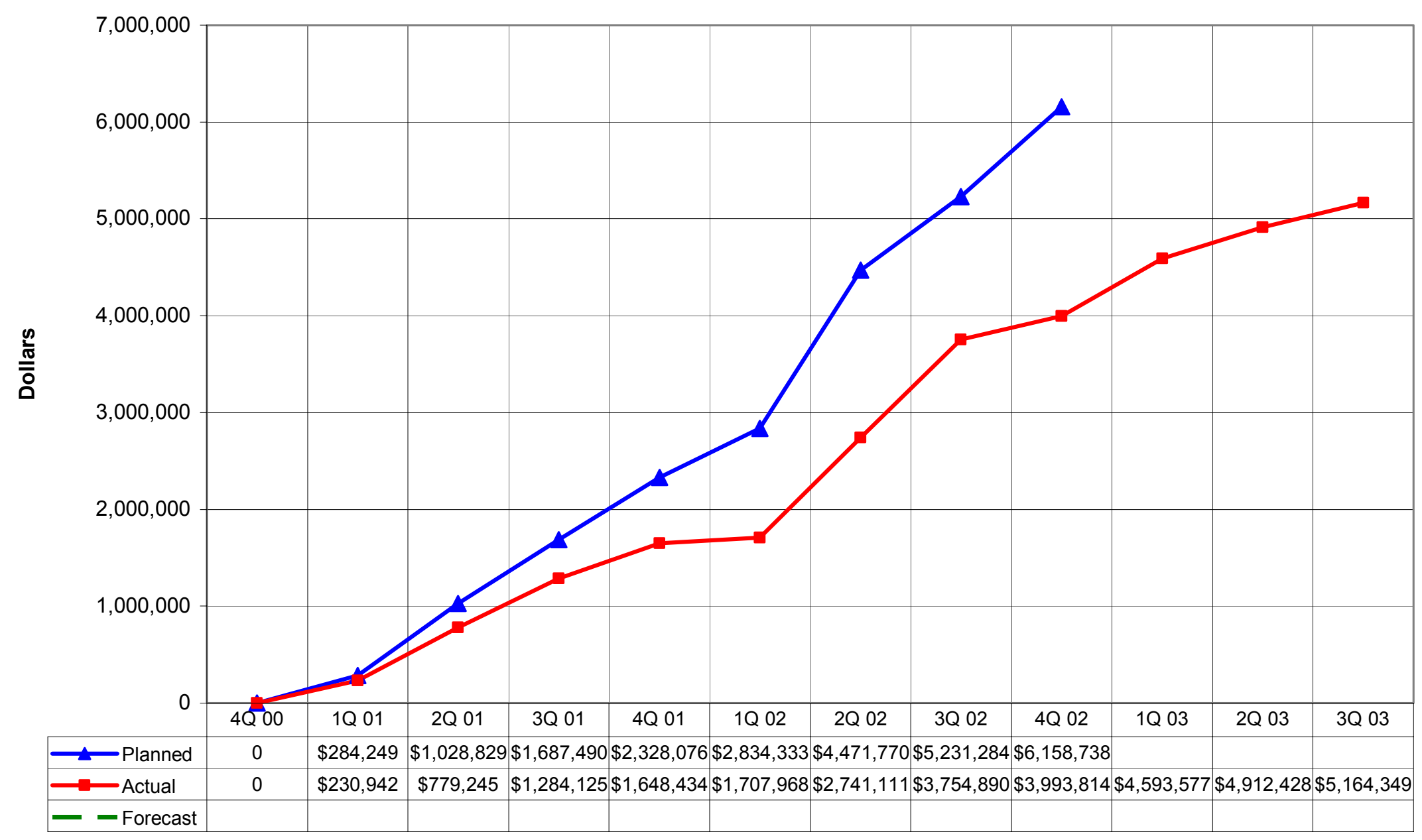




\section{Early Entrance Coproduction Plant}

Phase II - DOE Expenditures

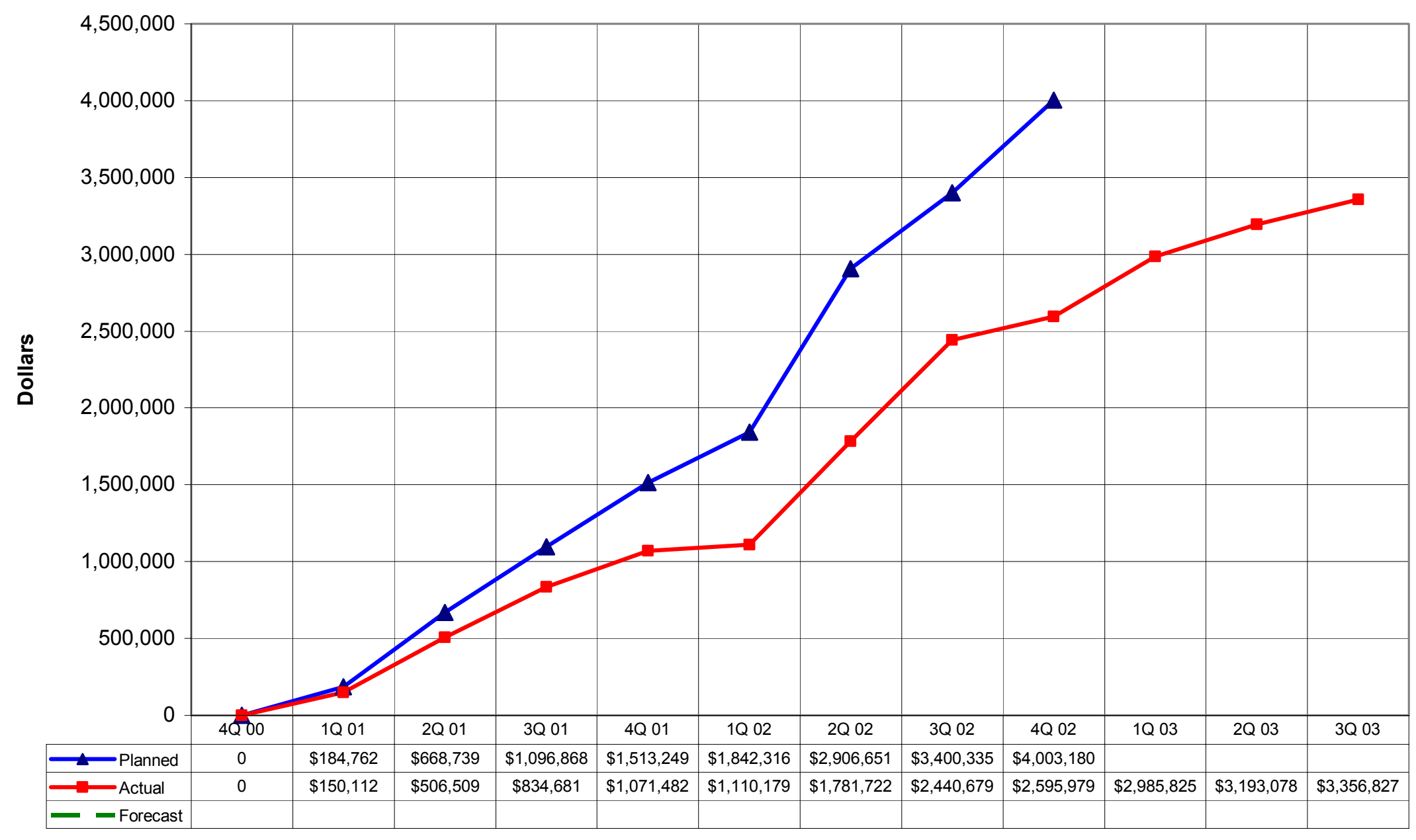


Early Entrance Coproduction Plant

Phase II - Total Percent Complete

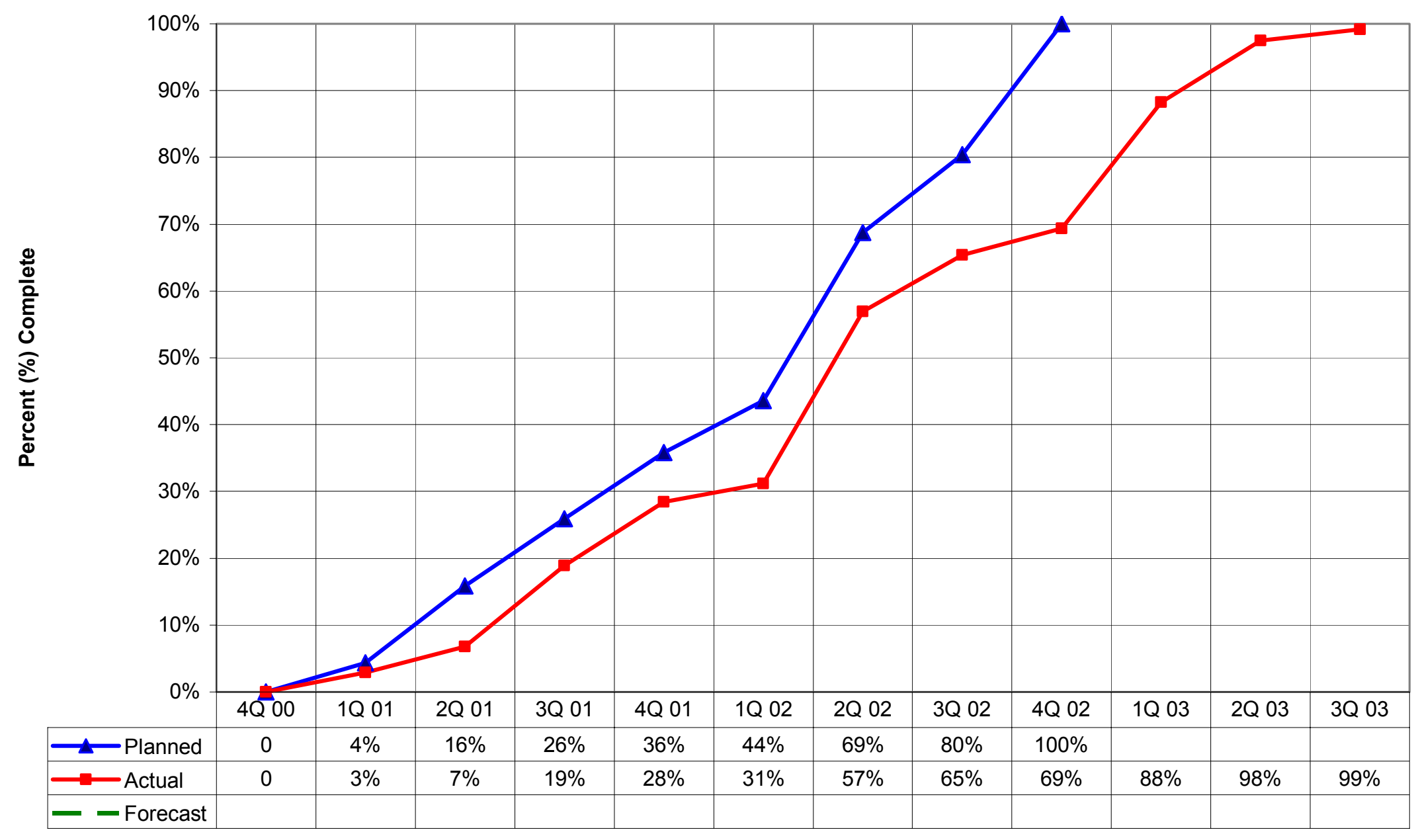




\section{Schedule}

The following schedule depicts the updated Phase II project schedule and shows percent complete by task as of September 30, 2003. For a description of the work involved in each task, refer to the Cooperative Agreement and the RD\&T Plan. This schedule was prepared using Microsoft Project 2000 software. Reporting is expected to be complete by December 31, 2003.

TES has requested DOE provide a no-cost time extension for Phase II of the EECP project from November 30, 2003 to March 31, 2004. The no-cost time extension would provide the opportunity to locate a new site and update the concept design basis prior to starting Phase III. 


\begin{tabular}{|c|c|c|c|c|c|c|c|c|c|c|c|c|c|c|c|}
\hline ID & Task Name & Start & Finish & 1001 & $2 Q 01$ & $3 \mathrm{QO} 01$ & 4001 & $1 \mathrm{Q02}$ & 2002 & 3002 & $4 Q 02$ & 1003 & $2 \mathrm{Q03}$ & $3 Q 03$ & 4003 \\
\hline & & & & 1,01 & 4,01 & 7,01 & 10,01 & 1,02 & 4,02 & 7,02 & 10,02 & 1,03 & 4,03 & $7 / 03$ & 10,03 \\
\hline 1 & Task 1 -- Project Management Plan & Mon $1 / 8 / 01$ & Wed 5/16/01 & & & & & & & & & & & & \\
\hline 2 & 1.1 Project Management Plan & Mon 1/8/01 & Fri 3/2/01 & & & & & & & & & & & & \\
\hline 6 & 1.2 Submit Project Management Plan to DOE & Fri 3/2/01 & Wed 5/16/01 & & & & & & & & & & & & \\
\hline 10 & 1.3 Submit Phase II Project Management Plan to DOE & Wed 5/16,01 & Wed 5/16,01 & & $\bullet$ & & & & & & & & & & \\
\hline 11 & Task 2--Engineering Analysis, Modeling, \& Experiment RD\&T & Mon 1/801 & Thu $1 / 2 / 03$ & & & & & & & & & & & & \\
\hline 12 & 2.0 Pre-RD\&T & Mon 1/8/01 & Fri 6/28/02 & & & & & & & & & & & & \\
\hline 16 & 2.1 Pilot Plant Confirmation & Mon 2/5/01 & Mon 3/10/03 & & & & & & & & & & & & \\
\hline 17 & 2.1.1 Catalyst Regeneration/rejuvenation & Mon 2/5/01 & Mon 3/10/03 & & & & & & & & & & & & \\
\hline 18 & 2.1.1.1 Deactivate catalyst for testing & Mon $4 / 2 / 01$ & Mon $9 / 3 / 01$ & & & & & & & & & & & & \\
\hline 19 & 2.1.1.2 Analysis of deactivated catalyst & Tue 9/4/01 & Mon 10/29:01 & & & & & & & & & & & & \\
\hline 20 & 2.1.1.3 Literature search & Mon 2/5\%1 & Thu $8 / 2,01$ & & & & & & & & & & & & \\
\hline 21 & 2.1.1.4 Laboratory testing & Mon 9/10/01 & Mon 3/10,03 & & & & & & & & & & & & \\
\hline 22 & 2.1.2 Catalyst AdditionMithdrawal & Mon 4/2/01 & Fri $1 / 18 / 02$ & & & & & & & & & & & & \\
\hline 25 & 2.1.3 Pilot testing in $\mathrm{BCR}$ & Mon $7 / 1,02$ & Fri $10 / 18 / 02$ & & & & & & & & & & & & \\
\hline 26 & 2.1.4 End of task report & Mon 10/21/02 & Mon 2/24/03 & & & & & & & & & & & & \\
\hline 32 & 2.2 Mathematical Model \& Reactor Scale-Up Confirmation & Mon 5/27/02 & Mon 4/7/03 & & & & & & & & & & & & \\
\hline 33 & 2.2.1 Confirm Mathernatical Model & Mon $5 / 27 / 02$ & Fri $11 / 29 / 02$ & & & & & & & & $=$ & & & & \\
\hline 34 & 2.2.2 End of task report & Fri 11/29/02 & Mon 4/7/03 & & & & & & & & & & & & \\
\hline 40 & 2.3 Catalyst Wax Separation & Mon 1/801 & Tue $8 / 5 / 03$ & & & & & & & & & & & & \\
\hline 41 & 2.3.1 Alternate F-T Catalystimax separation & Mon $7 / 2 / 01$ & Mon $3 / 31,03$ & & & & & & & & & & & & \\
\hline 42 & 2.3.2 Secondary F-T CatalystMax separation & Mon $1 / 801$ & Fri $12 / 21 / 01$ & & & & & & & & & & & & \\
\hline 43 & 2.3.3 End of task report & Tue 4/1/03 & Tue 8/5/03 & & & & & & & & & & & & \\
\hline 49 & 2.4 Low BTU Gas Combustion Test & Mon 7/9/01 & Mon 10/14/02 & & & & & & & & & & & & \\
\hline 50 & 2.4.1 Low BTU Gas Combustion Test & Mon 7/9:01 & Fri $6 \pi / 02$ & & & & & & & & & & & & \\
\hline 51 & 2.4.2 End of task report & Mon 6/10/02 & Mon 10/14/02 & & & & & & & & & & & & \\
\hline 57 & 2.5 F-T Product Upgrading & Mon 4/2/01 & Fri 10/17/03 & & & & & & & & & & & & \\
\hline 58 & 2.5.1 Preparation of LaPorte AFDU Product for Upgrading & Mon 4/2/01 & Thu 10/31/02 & & & & & & & & & & & & \\
\hline 60 & 2.5.2 Lab Batch Fractionation & Fri $11 / 1,02$ & Thu $12 / 26 / 02$ & & & & & & & & & & & & \\
\hline 61 & 2.5.3 Wax Hydrocracking Pilot Plant Run & Fri $11 / 1 / 02$ & Thu $2 / 6,03$ & & & & & & & & & & & & \\
\hline 62 & 2.5.4 Wax Finishing Pilot Plant Run & Mon $12 / 16 / 02$ & Tue $4 / 15 / 03$ & & & & & & & & & & & & \\
\hline
\end{tabular}




\begin{tabular}{|c|c|c|c|c|c|c|c|c|c|c|c|c|c|c|c|}
\hline ID & Task Name & Start & Finish & $1 \mathrm{Q01}$ & $2 Q 01$ & $3 Q 01$ & $4 Q 01$ & $1 \mathrm{Q02}$ & $2 \mathrm{Q02}$ & 3002 & $4 Q 02$ & $1 \mathrm{Q03}$ & $2 Q 03$ & 3003 & $4 Q 03$ \\
\hline & & & & 1,01 & 4,01 & 7,01 & 10,01 & 1,02 & 4,002 & 7,02 & 10002 & 1,03 & 4,03 & 7,03 & 10,03 \\
\hline 63 & 2.5.5 Characterization Testing & Fri $2 \pi / 03$ & Thu $4 / 3 / 03$ & & & & & & & & & & & & \\
\hline 64 & 2.5.6 Diesel Blending Testing & Mon 12/3/01 & Thu 5/15/03 & & & & & & & & & & & & \\
\hline 67 & 2.5.7 Naphtha Testing & Tue 1/1/02 & Fri 6/13/03 & & & & & & & & & & & & \\
\hline 68 & 2.5.7.1 Naphtha Fractionation & Tue $1 / 1,02$ & Mon $8 / 26,02$ & & & & & & & & & & & & \\
\hline 69 & 2.5.7.2 Naphtha Hydrotreating & Mon 1/6/03 & Fri $2 \pi / 03$ & & & & & & & & & & & & \\
\hline 70 & 2.5.7.3 Ethylene Cracker Yield Contirmation Tests & Thu $5 / 103$ & Wed $6 / 11,03$ & & & & & & & & & & & & \\
\hline 71 & 2.5.7.4 Fuel Cell Reformer Tests & Mon $2 / 10 / 03$ & Fri $6 / 13 / 03$ & & & & & & & & & & & & \\
\hline 72 & 2.5.7.6 Diesel Hydrotreating & Mon $2 / 10,03$ & Fri $2 / 21 / 03$ & & & & & & & & & 事 & & & \\
\hline 73 & 2.5.8 UIC Wax Fractionation & Fri $2 \pi / 03$ & Thu $6 / 12,03$ & & & & & & & & & & & & \\
\hline 74 & 2.5.9 End of task report & Fri 6/13/03 & Fri 10/17/03 & & & & & & & & & & & & \\
\hline 80 & 2.6 Fuel/Engine Performance and Emissions & Fri $2 / 7 / 03$ & Fri 10/10/03 & & & & & & & & & & & & \\
\hline 81 & 2.6.1 Lubricity Additive Testing & Fri $2 \pi / 03$ & Thu $3 / 6,03$ & & & & & & & & & & & & \\
\hline 82 & 2.6.2 Hot-Start Cycle Transient Engine Test & Fri $3 / 703$ & Thu $5 / 1,03$ & & & & & & & & & & & & \\
\hline 83 & 2.6.3 Solvent Extraction of Organic Fraction from DPM & Fri 5/2/03 & Thu $6 / 5,03$ & & & & & & & & & & & & \\
\hline 84 & 2.6.5 End of task report & Fri 6/6/03 & Fri 10/10/03 & & & & & & & & & & & & \\
\hline 90 & 2.7 Petroleum Coke Anabysis & Mon $6 / 4 / 01$ & Mon 8/19/02 & & & & & & & & & & & & \\
\hline 91 & 2.7.1 Petcoke assay & Mon 6/4/01 & Fri $4 / 12 / 02$ & & $\mathrm{w}$ & & & & , & & & & & & \\
\hline 92 & 2.7.2 End of task report & Mon 4/15/02 & Mon 8/19/02 & & & & & & & & & & & & \\
\hline 98 & 2.8 CO2 stripping from MDEA at medium pressure & Mon 4/2/01 & Mon 10/28/02 & & & & & & & & & & & & \\
\hline 99 & 2.8.1 Testing & Mon 4/2/01 & Fri 6/21/02 & & & & & & & & & & & & \\
\hline 104 & 2.8.2 End of task report & Mon $6 / 24 / 02$ & Mon 10/28/02 & & & & & & & & & & & & \\
\hline 110 & 2.9 Integration & Mon 6/4/01 & Mon 9/2/02 & & & & & & & & & & & & \\
\hline 111 & 2.9.1 Slurry wiF-T water & Mon 6/4:01 & Fri $10 / 5 / 01$ & & & & & & & & & & & & \\
\hline 112 & 2.9.1.1 Additonal Slurry Tests wiF-T water & Mon $4 / 1,02$ & Fri $4 / 26,02$ & & & & & & & & & & & & \\
\hline 113 & 2.9.2 End of task report & Mon $4 / 29 / 02$ & Mon 9/2/02 & & & & & & & & & & & & \\
\hline 119 & 2.10 Environmental & Mon 7/2/01 & Tue 11/4/03 & & & & & & & & & & & & \\
\hline 120 & 2.10.1 Slag \& fines characterization & Mon 108801 & Fri $6 / 28,02$ & & & & & & & & & & & & \\
\hline 121 & 2.10.2 F-T catalyst to gasifier & Mon 63302 & Fri $8 / 23 / 02$ & & & & & & & & & & & & \\
\hline 122 & 2.10.3 F-T catalyst disposal & Mon $6 / 3,02$ & Fri 10/4/02 & & & & & & & & & & & & \\
\hline 123 & 2.10.4 CO2 recovery from gas turbine & Mon $7 / 2 / 01$ & Mon $6 / 30 / 03$ & & & & & & & & & & & & \\
\hline
\end{tabular}


Early Entrance Coproduction Plant (EECP) - Phase II Schedule

\begin{tabular}{|c|c|c|c|c|c|c|c|c|c|c|c|c|c|c|c|}
\hline ID & Task Name & Start & Finish & $1 \mathrm{Q01}$ & $2 Q 01$ & 3001 & 4001 & $1 \mathrm{Q02}$ & $2 \mathrm{Q02}$ & 3002 & $4 Q 02$ & 1003 & $2 Q 03$ & $3 Q 03$ & $4 Q 03$ \\
\hline & & & & 1,01 & 4,01 & 7,01 & 10001 & 1,02 & 4,02 & 7,02 & 1002 & 1,03 & 4,03 & 7,03 & 1003 \\
\hline 124 & 2.10.5 End of task report & Tue 7/1/03 & Tue 11/4/03 & & & & & & & & & & & & \\
\hline 130 & 2.11 End of Task 2 Summary Report & Tue $9 / 2 / 03$ & Tue 12/16/03 & & & & & & & & & & & & \\
\hline 136 & Task 3--Updating \& Implementing Essential RD\&T & Mon 108801 & Tue $12 / 10 / 02$ & & & & & & & & & & & & \\
\hline 137 & 3.0 Critical \& Essential RD\&T Plan & Mon 10/8/01 & Mon 2/4/02 & & & & & & & & & & & & \\
\hline 144 & 3.1 Critical \& Essential RD\&T & Tue $2 / 5,02$ & Mon 11/11,02 & & & & & & & & & & & & \\
\hline 145 & 3.2 Preliminary Report & Tue 11/12/02 & Thu 1/9/03 & & & & & & & & & & & & \\
\hline 152 & 3.3 Final Report & Fri $1 / 10 / 03$ & Tue $2 / 11 / 03$ & & & & & & & & & & & & \\
\hline 155 & Task 4-Update Concept Basis of Design & Mon $5 / 27 / 02$ & Wed $1 / 1,03$ & & & & & & & & & & & & \\
\hline 156 & 4.1 Update the Concept Basis of Design & Mon 5/27/02 & Wed 10/30/02 & & & & & & & & & & & & \\
\hline 162 & 4.2 Submit the Concept Basis of Design to DOE & Wed 10/30/02 & Wed 1/1/03 & & & & & & & & & & & & \\
\hline 166 & 4.3 Submit the Updated Concept Basis of Design to DOE & Wed $1 / 1,03$ & Wed $1 / 1,03$ & & & & & & & & & & & & \\
\hline 167 & Administration & Mon 1/801 & Wed 12/31,03 & & & & & & & & & & & & \\
\hline
\end{tabular}

